\title{
PENGEMBANGAN PERANGKAT PEMBELAJARAN AKTIF MENGGUNAKAN METODE BERMAIN PERAN DI KELAS V SD
}

\author{
Mieke O. Mandagi \\ FIP-Universitas Negeri Manado \\ Jln. Todano, Koya Kabupaten Minahasa Sulawesi Utara \\ Email: mikemandagi@gmail.com.
}

\begin{abstract}
The study aims at developing active teaching instrument within the materials of human blood circulation using role play strategy. The development referred to 4-D (Thiagarajan) which are defining, designing, and developing. The product was implemented to thirty-fifth-grade students at SDN 1 Ketintang Surabaya. The data were analysed in the descriptive qualitative analysis. The result of the textbook, students' worksheet, lesson plan and triwulan assessment validation have been good and proper to be used. The result of implementation showed that: 1) the dominant activity of students (15.6\%) simulated the role play, 2) Learning process was well implemented, 3) students mastery were $100 \%$, 4) students motivation and interest toward active learning by using role play were categorized as good.
\end{abstract}

Keywords: active teaching instrument, role play strategy, human blood circulation for primary school.

\begin{abstract}
Abstrak: Penelitian bertujuan mengembangkan perangkat pembelajaran aktif (buku ajar, LKS, RPP danTHB) materi peredaran darah manusia menggunakan metode bermain peran. Pengembangan mengacu model 4-D (Thiagarajan) yaitu pendefinisian, perancangan, dan pengembangan. Implementasi produk pada siswa kelas V SDN I Ketintang Surabaya berjumlah 31 orang.Analisis secara deskriptif kualitatif.Hasil validasi buku ajar, LKS, RPP dan THB menunjukkan kualitas yang sudah baik, dan layak digunakan. Hasil implementasi menunjukkan:(1) aktivitas belajar siswa yang dominan (15.6\%) adalah mensimulasikan kegiatan bermain peran, (2) keterlaksanaan pembelajaran berkategori baik, (3) ketuntasan hasil belajar siswa $100 \%$, (4) minat dan motivasi siswa terhadap pembelajaran aktif menggunakan metode bermain peran berkategori baik.
\end{abstract}

Kata kunci: perangkat pembelajaran aktif, metode bermain peran, peredaran darah manusia SD.

Pendidikan dasar khususnya pada Sekolah Dasar (SD), merupakan fondasi pendidikan bukan hanya bagi pendidikan pada jenjang selanjutnya, tetapi juga pendidikan bagi semua warga negara. Mutu pendidikan bagi warga negara umumnya dan mutu pendidikan lanjutan khususnya sangat bergantung pada mutu pendidikan SD. Mutu hasil pendidikan sebagian besar ditentukan oleh mutu kegiatan belajar mengajar Mulyasa (2006). Sehubungan dengan itu, peningkatan mutu KBM di SD merupakan kebutuhan yang mutlak.

Ilmu Pengetahuan Alam (IPA) adalah salah satu mata pelajaran yang terdapat di SD. Salah satu aspek pembelajaran ilmu pengetahuan alam yang sering mendapat perhatian khusus adalah strategi belajar mengajar. Hal ini terlihat dengan adanya kritikan maupun upaya-upaya konstruktif dari pihak tertentu untuk mengusahakan pengembangan 
strategi tersebut agar siswa lebih menguasai dan dapat mengaplikasikannya dalam kehidupan seharihari Sukandi (2003:2).

Settles (2010) mengungkapkan bahwa pembelajaran berparadigma active learning memberikan peluang kepada peserta didik untuk lebih proaktif dalam menyelesesaikan permasalahan yang ada di dalam proses pembelajaran. Haak, dkk (2011) memberikan penelitian bahwa pembelajaran aktif lebih memudahkan dalam memperkenalkan biologi kepada peserta didik pada satuan pendidikan dasar. Lebih khusus lagi penelitian ini memberikan penjelasan bahwa efektivitas pembelajaran aktif lebih terkondisi jika menggunakan paradigma pembelajaran aktif. Russel, dkk (2010:993) memberikan penjelasan bahwa pembelajaran berbasis permainan memiliki peluang dalam meningkatkan kemampuan peserta didik dalam hal pencapaian kinerja dalam proses pembelajaran. Pettenger (2014) $\mathrm{dkk}$, mengungkapkan bahwa proses penilaian berbasis pembelajaran aktif, meski memperhatikan prinsip kemudahan serta lebih digunakan untuk proses pengembangan diri.

Mempelajari IPA ternyata sangat berhubungan erat dengan kehidupan sehari-hari. Hal ini sangat nyata dijabarkan dalam kurikulum IPA. Dalam kurikulum dijelaskan bahwa IPA berhubungan dengan cara mencari tahu tentang alam secara sistematis, sehingga IPA bukan hanya penguasaan kumpulan pengetahuan yang berupa fakta-fakta, konsep-konsep, atau prinsip-prinsip saja tetapi juga merupakan suatu proses penemuan KTSP (Pusat Kurikulum, 2006:110).

Pendidikan IPA diarahkan untuk melakukan inkuiri dan berbuat sehingga dapat membantu peserta didik untuk memperoleh pemahaman yang lebih mendalam tentang alam sekitar Kurikulum KTSP (2006). Pada kenyataannya, dalam pendidikan IPA di SD masih kurang terlihat siswa diberi kesempatan untuk mengembangkan kemampuan dalam mengambil keputusan dalam hubungannya dengan masalah sederhana yang ada di sekitarnya dan pengembangan kesadaran karier dirinya sendiri sebab itu perlu adanya perubahan dalam proses pembelajaran (Sukandi, 2003:2).

Menurut teori konstruktivisme, pengajaran hendaknya berpusat pada siswa, yang berperan aktif adalah siswa, sedangkan peran guru adalah membantu siswa menemukan fakta, konsep atau prinsip bagi diri mereka sendiri, bukan memberi ceramah atau mengendalikan seluruh kegiatan kelas Nur (2002). Oleh sebab itu perlu adanya inovasi dalam pembelajaran IPA sebagai upaya untuk membelajarkan siswa agar dapat belajar secara optimal.

Untuk itu melalui Proyek Pengembangan Pendidikan Guru (P3G) mencanangkan suatu pendekatan pembelajaran yang dinamakan belajar aktif Sukandi (2003:2). Pendekatan belajar aktif adalah cara pandang yang menganggap belajar sebagai kegiatan yang membangun makna atau pengertian terhadap pengalaman dan informasi, yang dilakukan oleh pebelajar, bukan oleh pengajar, serta menganggap mengajar sebagai kegiatan menciptakan suasana yang mengembangkan inisiatif dan tanggung jawab Sukandi (2003). Belajar aktif sangat diperlukan oleh peserta didik untuk mendapatkan hasil belajar yang maksimal. Pembelajaran aktif melibatkan siswa, ketika siswa bersemangat, siap secara mental dan bisa memahami pengalaman yang dialaminya Lewis (2007).

Salah satu pendekatan yang dapat digunakan untuk melaksanakan pembelajaran aktif adalah metode bermain peran. Bermain peran adalah suatu aktivitas pembelajaran yang terencana yang dirancang untuk mencapai tujuan-tujuan pendidikan yang spesifik Zaini, (2007:101). Menurut Yulianto (2008:9) salah satu strategi pembelajaran yang dapat dipilih untuk mendukung metode pembelajaran adalah bermain peran. Dalam pelaksanaannya siswa memainkan suatu peran yang masuk dalam situasi yang bersifat simulasi atau skenario, yang dipilih berdasarkan relevansi dengan pengetahuan yang sedang dipelajari peserta atau materi kurikulum.

Salah satu hasil penelitian dari Badan Penelilitian dan Pengembangan Pendidikan dan Kebudayaan (Balitbang DikBud) mengungkapkan bahwa jarang guru menggunakan metode mengajar bermain peran, bercerita dan permainan, padahal metode tersebut sangat bermanfaat bagi anak sekolah dasar (Sukandi, 2003:2).Penelitian lain juga menyimpulkan bahwa mengajarkan anak dengan mengunakan metode permainan dapat memajukan aspek-aspek perkembangan anak seperti motorik, kreativitas, kecakapan-kecakapan sosial dan kognitif serta perkembangan motivasional dan emosional Monks \& Hadinoto, (dalam Dwiningsih, 2005:37). 
Berdasarkan uraian di atas dipilih salah satu pokok bahasan IPA SD yang tercantum dalam silabus Kurikulum Tingkat Satuan Pendidikan yaitu peredaran darah pada manusia yang diajarkan di kelas V SD. Pokok bahasan ini meliputi tiga sub pokok bahasan yaitu darah dan organ peredaran darah pada manusia, proses peredaran darah pada manusia, gangguan organ peredaran darah pada manusia.Sub pokok bahasan untuk materi organ peredaran darah pada manusia dan proses peredaran darah adalah abstrak. Untuk siswa sekolah dasar yang masih berada pada tahap konkret maka materi yang bersifat abstrak setidaknya guru berusaha membuat materi tersebut sekonkret mungkin sehingga mudah diserap oleh siswa.

Sejalan dengan itu pula menurut pendapat Mintohari (2005:82) mengatakan bahwa untuk mengajarkan materi aliran darah yang terjadi pada manusia tidak dapat diamati dari luar. Aliran darah tersebut juga tidak dapat dieksperimenkan dengan alat apapun sampai saat ini. Untuk lebih memahami aliran darah dalam tubuh manusia, siswa dapat bermain peran bersama beberapa orang teman. Pendapat ini juga dikemukakan oleh Yulianto (2008:9) bahwa bila situasi alami untuk jenis tuturan tertentu tidak mungkin dilakukan, dapat dilakukan peniruannya, yakni melalui kegiatan bermain peran. Pada materi darah dan organ peredaran darah pada manusia, proses peredaran kecil dan proses peredaran darah besar diajarkan dengan menggunakan metode bermain. Karena pada metode bermain peran, siswa dapat memerankan materimateri yang abstrak menjadi lebih konkrit. Dengan metode bermain peran siswa tidak hanya menghafal materi, tetapi juga memerankan dari isi materi tersebut. Pada materi gangguan organ peredaran darah pada manusia yang diajarkan pada siswa adalah jenis gangguan, faktor penyebab dan gejala yang ditimbulkan. Untuk sub pokok bahasan gangguan pada organ peredaran darah juga diajarkan dengan menggunakan metode bermain peran dimana pembelajaran tidak lagi berpusat pada guru, karena siswa juga aktif.

\section{Pembelajaran Aktif}

Belajar aktif adalah cara pandang yang menganggap belajar sebagai kegiatan membangun makna atau pengertian terhadap pengalaman dan informasi, yang dilakukan oleh si pebelajar, bukan oleh si pengajar, serta menganggap mengajar sebagai kegiatan menciptakan suasana yang mengembangkan inisiatif dan tanggungjawab belajar si pebelajar sehingga berkeinginan belajar terus selama hidupnya, dan tidak tergantung kepada orang lain bila mereka mempelajari hal-hal baru Sukandi (2003:6).

Dengan belajar aktif ini, peserta didik diajak untuk turut serta dalam semua proses pembelajaran, tidak hanya mental akan tetapi juga melibatkan fisik. Sehingga peserta didik akan merasakan suasana yang lebih menyenangkan dan hasil belajar dapat dimaksimalkan Zaini (2007). Belajar aktif adalah salah satu cara untuk mengikat informasi yang baru kemudian menyimpannya kembali ke dalam otak. Belajar yang hanya mengandalkan indera pendengaran mempunyai kelemahan, padahal hasil belajar seharusnya disimpan sampai waktu yang lama.

Karakteristik pembelajaran aktif terlihat dalam keterlibatan siswa saat kegiatan belajar-mengajar. Siswa dilibatkan berpikir pada tingkat yang lebih tinggi yaitu pada tahap analisis, sintesis dan evaluasi. Siswa beraktivitas membaca, diskusi dan menulis. Mendorong siswa untuk mengaplikasikan apa yang dimilikinya, mencoba keterampilanketerampilan dan melakukan tugas-tugas yang tergantung pada pengetahuan yang mereka miliki atau yang harus mereka capai Bowel \& Eison (dalam Agustiningsih, 2006). Dari sisi pengajar atau guru, sebagai penyampaian materi, strategi pembelajaran aktif akan sangat membantu dalam melaksanakan tugas-tugas keseharian. Bagi guru yang harus mengajar beberapa kelas dalam satu hari, dapat dibayangkan betapa lelahnya guru tersebut kalau harus menggunakan metode ceramah sehingga metode ini bisa digunakan.

Metode Bermain Peran merupakan suatu strategi pembelajaran dimana terdapat peran-peran yang dapat didefenisikan dengan jelas,yang memiliki interaksi yang mungkin dieksplorasidalam keadaan yang bersifat simulasi (Zaini, 2007:103). Kelebihan metode bermain peran bagi siswa menurut Zaini (2007) adalah: (a) mendemonstrasikan pengetahuan, ketrampilan dan kemampuan yang diperoleh, (b) mendemonstrasikan intergrasi pengetahuan praktis, (c) membandingkan dan mengkontraskan posisiposisi yang diambil dalam pokok permasalahan, (d) menerapkan pengetahuan pada pemecahan masalah, (e) menjadikan problem yang abstrak menjadi konkrit, (f) melibatkan siswa dalam pembelajaran 
yang langsung dan eksperiensial, (g) mendorong pembelajaran seumur hidup, (h) mempelajari bidang tertentu dari kurikulum secara selektif, (i) memfasilitasi ekspresi sikap dan perasaan siswa dengan sah, (j) mengembangkan pemahaman yang empatik, dan (k) memberi feedbak yang segera bagi guru dan siswa.

Dalam menggunakan metode bermain peran siswa diminta untuk mengandaikan suatu peran khusus. Siswa bertindak persis sebagaimana pandangan mereka terhadap orang yang diperankan dalam situasi-situasi tertentu ini, dengan menyepakati untuk bertindak "seolah-olah" peran-peran tersebut adalah peran-peran mereka sendiri (Jones dalam Zaini, 2007:102) dan bertindak berdasarkan asumsi tersebut (Milroy dalam Zaini, 2007:102). Siswa dapat juga menggunakan pengalaman-pengalaman peran yang sama pada masa lalu untuk untuk mengisi suatu peran singkat yang ditentukan Lowe \& Lewis (dalam Zaini, 2007:102).

Adapun sintaks metode bermain peran yang dikembangkan oleh peneliti terdiri dari 6 tahap, yaitu (1) menjelaskan metode bermain peran, (2) membagi peran, (3)mengarahkan pada siswa mengenai langkah-langkah yang akan disimulasikan, (4) mengatur dan mengamati kegiatan simulasi, (5) menginformasikan pada siswa yang tidak terlibat dalam kegiatan simulasi untuk memperhatikan jalannya simulasi, (6) refleksi atau evaluasi kegiatan simulasi dengan menggunakan metode bermain peran.

\section{Tabel 1. Fase-Fase Metode Bermain Peran yang Dikembangkan}

\begin{tabular}{l}
\hline \multicolumn{1}{c}{ Perilaku Guru } \\
\hline Fase 1. Guru menjelaskan pada siswa mengenai \\
metode bermain peran \\
Fase 2. Guru membagi peran \\
Fase 3. Guru mengarahkan pada siswa mengenai \\
langkah-langkah yang akan disimu-lasikan \\
Fase 4. Guru mengamati dan mengatur jalannya \\
simulasi bermain peran \\
Fase 5. Guru menginformasikan pada siswa yang \\
tidak terlibat simu-lasi untuk mengamati dan mem- \\
perhatikan kegiatan simulasi teman \\
Fase 6. Guru memberikan refleksi atau evaluasi ter- \\
hadap kegiatan simulasi bermain peran
\end{tabular}

\section{Teori Pendukung Pembelajaran}

Kesatu, Teori Konstruktivis, menyatakan bahwa siswa harus menemukan sendiri dan mentransformasikan informasi komlpeks, mengecek informasi baru dengan aturan-aturan lama dan merevisinya apabila aturan itu tidak lagi sesuai. Dalam proses belajar mengajar keaktifan siswa dalam membangun makna atau pemahaman sangat penting agar pembelajaran bermanfaat. Tanggungjawab belajar berada pada diri siswa, guru bertangung jawab untuk menciptakan situasi yang dapat mendorong siswa belajar sepanjang hayat, siswa dibiasakan untuk memecahkan masalah, dan menentukan sesuatu yang berguna bagi dirinya. Dengan kata lain siswa harus mengkonstruksi pengetahuan dibenaknya sendiri (Nur, 2002).

Kedua, Teori Perkembangan Kognitif Piaget. Perkembangan kognitif sebagian besar ditentukan oleh manipulasi dan interaksi aktif anak dengan lingkungan. Pengetahuan datang dari tindakan. Piaget yakin bahwa pengalaman-pengalaman fisik dan manipulasi lingkungan penting bagi terjadinya perubahan perkembangan. Sementara itu bahwa interaksi sosial dengan teman sebaya, khususnya berargumentasi dan berdiskusi membantu memperjelas pemikiran yang pada akhirnya memuat pikiran itu menjadi lebih logis (Trianto, 2007).Teori Piaget menyimpulkan bahwa implikasi pembelajaran terutama untuk: (1) memusatkan pada berpikir siswa tidak hanya pada prosesnya, (2) mengutamakan peran siswa dalam berinisiatif sendiri dan keterlibatan siswa dalam kegiatan pembelajaran, (3) menerima perbedaan individual dalam hal kemajuan perkembangan anak (Trianto, 2007).

Ketiga, Teori Penemuan Jerome Bruner. Bruner menyarankan agar siswa hendaknya belajar melalui partisipasi secara aktif dengan konsepkonsep dan prinsip-prinsip, agar mereka dianjurkan untuk memperoleh pengalaman dan melakukan eksperimen-eksperimen yang mengizinkan mereka untuk menemukan prinsip-prinsip itu sendiri.Guru harus mendorong dan memberikan motivasi kepada siswa untuk memecahkan sendiri masalah yang dihadapinya bukan mengajarkan mereka jawaban dari masalah yang dihadapi tersebut. Motivasi belajar memberikan konstribusi yang positif terhadap hasil belajar siswa (Uno dalam Astawan. 2014:171). Siswa akan mendapat keuntungan 
jika mereka dapat melihat dan melakukan sesuatu daripada hanya sekedar mendengarkan ceramah. Guru dapat membantu siswa memahami konsep yang sulit dengan bantuan gambar dan demonstrasi (Nur, 2008).

Keempat, Teori pembelajaran sosial merupakan perluasan dari teori perilaku tradisioanal. Teori ini menerapkan prinsip-prinsip teori pembelajaran perilaku dan penekanannya pada proses mental internal. Teori ini dikembangkan oleh Albert Bandura. Inti dari teori pembelajaran sosial adalah pemodelan.

\section{Karakteristik Materi Peredaran Darah Manusia}

Salah satu materi pada pokok bahasan IPA SD yang tercantum dalam silabus Kurikulum Tingkat Satuan Pendidikan yaitu peredaran darah manusia yang diajarkan di kelas V SD. Pokok bahasan ini merupakan materi yang memang berhubungan dengan diri siswa sendiri, tetapi bersifat abstrak. Menurut Piaget (dalam Nur 2002) anak yang dengan usia 10-11 tahun berada pada tahap operasional konkrit. Jadi untuk mencapai tujuan pembelajaran perlu adanya suatu metode pembelajaran yang membuat materi tersebut lebih konkrit. Untuk itulah peneliti mengambil pendekatan belajar aktif dengan menggunakan metode bermain peran dalam mengajarkan pokok bahasan peredaran darah manusia. Pokok bahasan peredaran darah manusia yang digunakan dalam penelitian ini meliputi tiga sub pokok bahasan yaitu darah dan organ peredaran darah, proses peredaran darah serta gangguan pada organ peredaran darah manusia..

Berdasarkan uraian di atas, untuk materi darah dan organ peredaran darah, proses peredaran kecil dan besar serta gangguan organ peredaran darah juga diajarkan dengan menggunakan metode bermain peran. Dengan menerapkan metode bermain peran pembelajaran tidak lagi berpusat pada guru, karena siswa juga aktif dalam proses pembelajaran.

\section{Implementasi Pembelajaran Aktif dengan Menggunakan Metode Bermain Peran pada Pokok Bahasan Peredaran Manusia}

Dalam pelaksanaannya siswa memainkan suatu peran yang masuk dalam situasi yang bersifat simulasi atau skenario, yang dipilih berdasarkan

Tujuan :

Mengembangkan perangkat pembelajaran IPA SD berorientasi pembelajaran aktif dengan menggunakan metode bermain peran, yang dilihat dari aktivitas belajar siswa, keterlaksanaan RPP, hasil belajar siswa dan respon siswa terhadap pembelajaran pada pokok bahasan peredaran darah manusia.

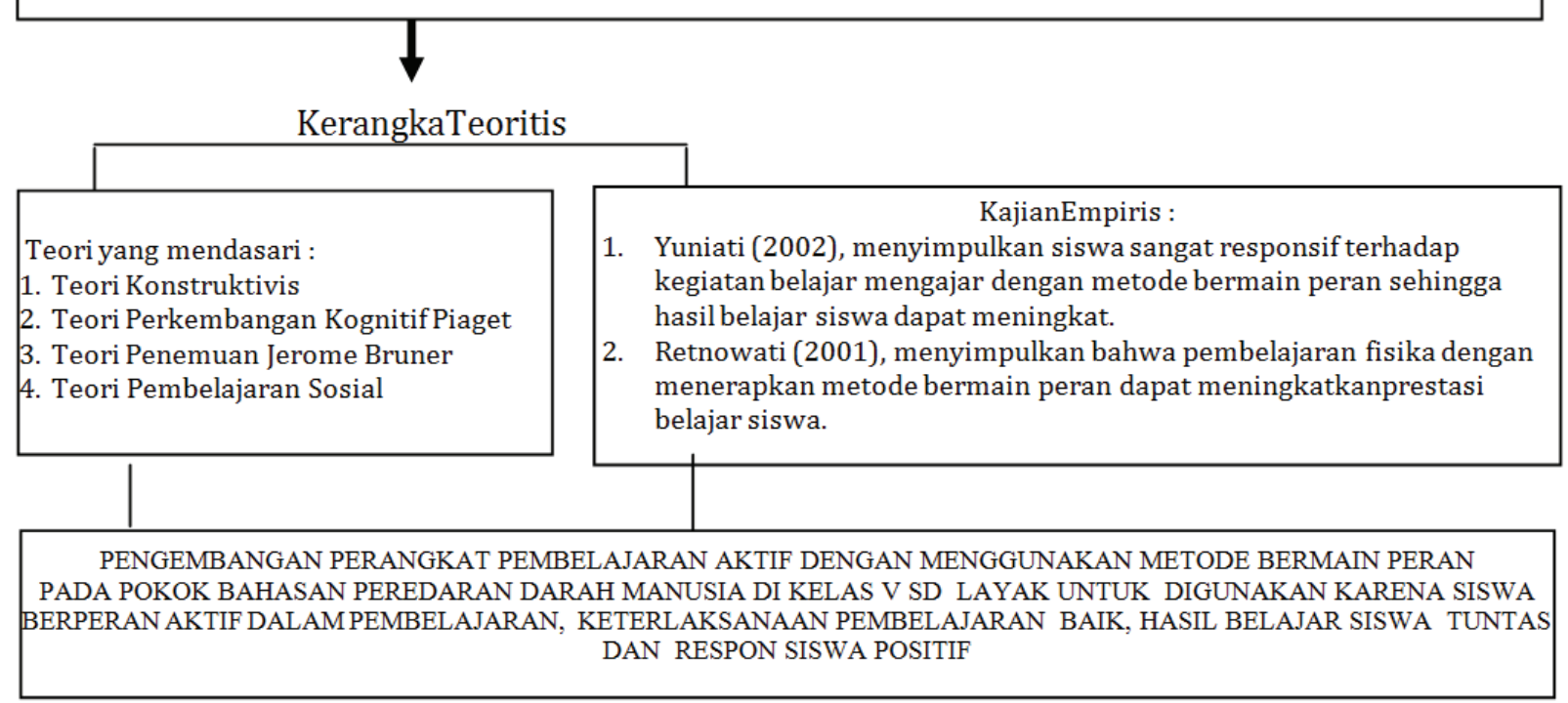

Gambar 1. Paparan Kerangka Konseptual 
relevansi dengan pengetahuan yang sedang dipelajari peserta atau materi kurikulum Zaini, (2007). Mengajarkan anak dengan menggunakan metode permainan dapat memajukan aspek-aspek perkembangan anak seperti motorik, kreativitas, kecakapan-kecakapan sosial dan kognitif serta perkembangan motivasional dan emosional Monks \& Hadinoto, (dalam Dwiningsih 2005:37).

Dengan metode bermain peransiswa secara aktif menggunakan otak, baik untuk menemukan ide pokok dari materi pembelajaran, memecahkan persoalan atau mengaplikasikan apa yang baru dipelajari. Dengan metode bermain peran peserta didik diajak untuk turut serta dalam semuaproses pembelajaran, tidak hanya mental, akan tetapi juga melibatkan fisik dimana saja terdapat peranperan yang dapat didefenisikan dengan jelas, yang memiliki interaksi yang mungkin dieksplorasi dalam keadaan yang bersifat simulasi atau skenario sehingga peserta didik akan merasakan suasana yang lebih menyenangkan sehingga hasil belajar dapat dimaksimalkan.

\section{Kerangka Konseptual}

Bedasarkan paparan di atas yang menjadi tujuan penelitian pengembangan ini adalah: (1) menghasilkan produk berupa buku ajar siswa yang berorientasi pembelajaran aktif dengan menggunakan metode bermain peran dengan pokok bahasan peredaran darah manusia. Produk pengembangan termasuk (a) lembar kerja siswa, (b) rencana pelaksanaan pembelajaran aktif, (c) tes hasil belajar siswa (THB) yang berorientasi pembelajaran aktif dengan menggunakan metode ber-main peran pada pokok bahasan peredaran darah manusia. Implementasi perangkat pembelajaran aktif dengan menggunakan metode bermain peran pada pokok bahasan peredaran darah manusia dilihat dari: (a) aktivitas siswa, (b) keterlaksanaan rencana pembelajaran aktif, (c) hasil belajar siswa setelah mengikuti pembelajaran aktif dengan menggunakan metode bermain peran pada pokok bahasan peredaran darah manusia.

\section{METODE}

Penelitian ini termasuk penelitian pengembangan, yaitu mengembangkan perangkat pembelajaran berupa Rencana Pelaksanaan Pembelajaran (RPP), Bahan Ajar Siswa (BAS), Lembar Kegiatan

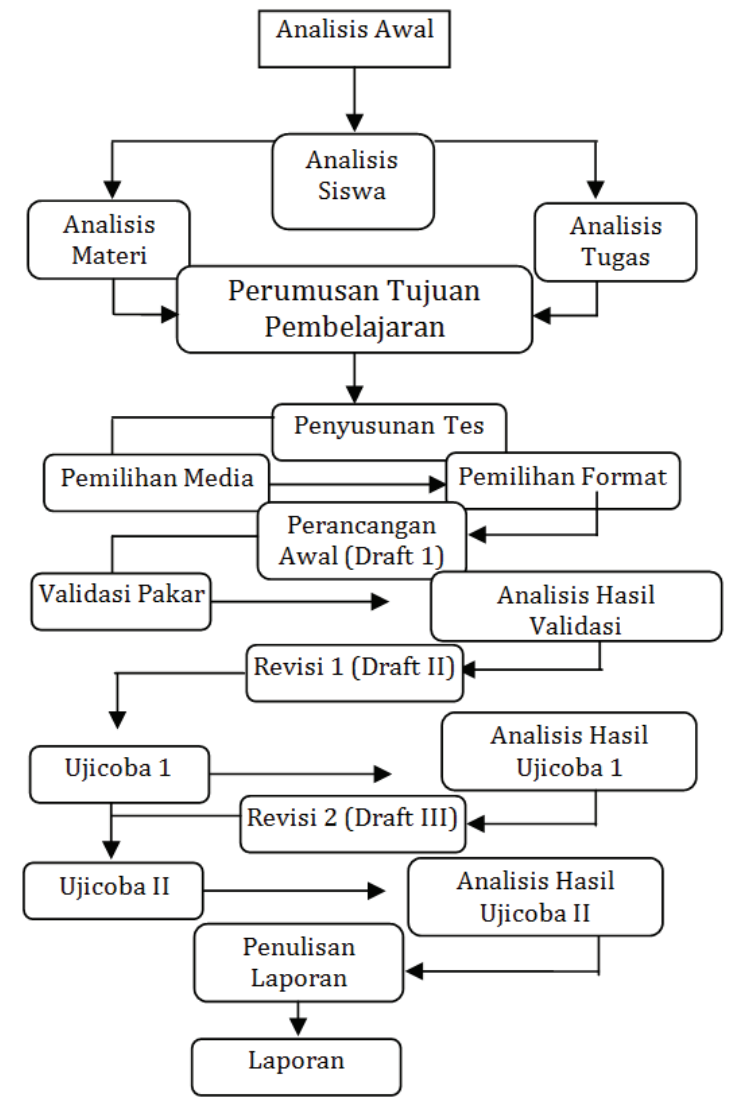

Gambar 2. Perangkat pengembangan

Siswa (LKS), dan Tes Hasil Belajar (THB). Disamping itu jenis penelitian ini termasuk penelitian deskriptif, yang mendeskripsikan hasil belajar siswa, aktivitas belajar siswa, aktivitas guru, keterlaksanaan pembelajaran dan respons siswa.

Subyek penelitian ini adalah siswa kelas V SD Negeri I Ketintang Surabaya, yang mengikuti pembelajaran IPA pada pokok bahasan peredaran darah pada manusia semester I dengan jumlah 31 siswa. Tahap-tahap pengembangan perangkat disajikan dalam bentuk diagram pada gambar 2 .

Model pengembangan yang digunakan adalah model 4-Ds Thiagarajan (1974:5). Peneliti menggunakan model ini karena lebih terperinci dan sistimatis sehingga memudahkan untuk melakukan proses pengembangan perangkat pembelajaran. Model ini terdiri dari 4 (empat) tahapan yaitu pendefinisian (Define), perancangan (Design), pengembangan (Develop) dan penyebaran (Disseminate). Dalam penelitian ini pengembangan perangkat hanya sampai pada 3 tahap saja, yaitu tahap pendefenisisan, tahap perancangan, dan tahap pengembangan. Tahap penyebaran tidak dilakukan karena tujuan penelitian hanya sam- 
pai pada tahap pengembangan perangkat dan selanjutnya penulisan laporan.

Instrumen penelitian yang digunakan: (1) Tes, digunakan untuk menilai dan mengukur hasil belajar siswa, terutama hasil belajar kognitif berkenaan dengan penguasaan bahan pengajaran sesuai dengan tujuan pembelajaran. Bentuk tes yang dikembangkan peneliti terdiri dari 25 butir soal pilihan ganda dan 3 butir soal uraian. Validitas butir tes diperoleh dengan menghitung sensivitas tiap butir tes. Sensivitas suatu tes adalah kemampuan tes tersebut untuk mengukur efek pembelajaran (Muslimin 2006). Untuk mengetahui sensivitas butir soal maka siswa diberikan uji awal dan uji akhir dengan soal tes yang sama. Soal akan dikatakan sensitif bila soal dapat dijawab lebih banyak pada saat uji akhir. Untuk menghitung sensivitas butir soal digunakan rumus

$$
\begin{array}{ll}
R_{A}^{-} & R_{B} \\
\quad \mathrm{~S}=
\end{array}
$$

\section{$\mathrm{T}$}

(Gronlund dalam Ibrahim, 2006)

Dimana,

$\mathrm{S}=$ Indeks sensivitas

RA = Jumlah siswa yang dapat menjawab dengan benar sesudahberlangsung kegiatan belajar mengajar

$\mathrm{RB}=$ jumlah siswa yang dapat menjawab dengan benar sebelum berlangsung kegiatan belajar mengajar

$\mathrm{T}=$ total jumlah seluruh siswa

Harga sensivitas yang besar menunjukan tingkat sensivitas tinggi, sedangkan harga yang kecil menunjukkan tingkat sensivitas rendah. Kriteria yang dipakai untuk menyatakan bahwa setiap butir soal sensitive terhadap efek-efek pembelajaran adalah nilai sensivitas lebih besar atau sama dengan 0,30 (Ibrahim, 2006).

(2) Lembar Pengamatan Aktivitas Belajar Siswa, merupakan instrumen untuk mengukur tingkah laku siswa ataupun proses terjadinya suatu kegiatan yang dapat diamati selama proses belajar mengajar berlangsung. Kategori pengamatan meliputi aktivitas siswa dalam memperhatikan penyajian guru, memberikan tanggapan, mengajukan pertanyaan, membagi peran, mensimulasikan kegiatan bermain peran, mengamati atau memperhatikan kegiatan simulasi, refleksi dan evaluasi, mengerjakan LKS, membahas LKS, membuat rangkuman dan kegiatan yang tidak relevan dengan KBM.
(3) Lembar Pengamatan Keterlaksanaan Pembelajaran, untuk mengukur keterlaksanaan pembelajaran, dengan tujuan untuk merekam perilaku guru dalam melaksanakan langkah-langkah kegiatan belajar mengajar yang telah direncanakan dalam RPP. Pengamatan dilakukan oleh pengamat tentang perilaku guru dan pencatatan dilakukan setiap langkah-langkah kegiatan belajar mengajar selesai dilaksanakan.Reliabilitas instrumen aktivitas siswa selama pembelajaran dan keterlaksanaan pembelajaran dihitung dengan menggunakan teknik percentage of Agreement Borich, (dalam Ibrahim, 2006)

$$
\text { Persentage of Agreement }\left(R^{k}\right)=\left(1-\frac{A-B}{A+B}\right) \times 100 \%
$$

Keterangan:

$\mathrm{R}^{\mathrm{k}}=$ Koefisien Reliabilitas

A $=$ Frekuensi aspek tingkah laku yang teramati oleh pengamat dengan frekuensi tinggi.

$\mathrm{B}=$ Frekuensi aspek tingkah laku yang teramati oleh pengamat dengan frekuensi rendah.

Instrumen dikategorikan baik (reliabel) jika nilai reliabilitas yang diperoleh $(\mathrm{R})^{3} \quad 0,75$ (75\%) Borich, (dalam Ibrahim, 2006).

(4) Lembar Angket Respon Siswa, yang dikembangkan peneliti dan diberikan kepada siswa setelah selesai pembelajaran atau diberikan pada akhir penelitian. Bertujuan untuk mengetahui minat dan motivasi siswa terhadap kegiatan belajar mengajar dengan menggunakan metode bermain peran.

Teknik pengumpulan data dilakukan dengan cara observasi, pemberian tes hasil belajar, dan penyebaran angket. Teknik analisis data yang digunakan adalah statistik deskriptif. Analisis data aktivitas siswa dalam pembelajaran menggunakan statistik deskriptif dengan persentase. Analisis data keterlaksanaan pembelajaran dilakukan oleh pengamat dihitung berdasarkan skor ratarata untuk tiap-tiap RPP dengan menggunakan ketentuan kriteria berikut: 1=kurang baik, $2=$ cukup baik, 3=baik, 4=sangat baik. Skor yang diperoleh dijumlahkan kemudian dirata-ratakan dari setiap aspek keterlaksanaan pembelajaran.Analisis data hasil belajar siswa dianalisis dengan menggunakan statistik deskripif, yaitu dengan menggunakan tingkat ketuntasan individual dan klasikal. Untuk 
menghitung ketuntasan hasil belajar siswa, peneliti mengacu pada ketuntasan yang ditentukan oleh SD Negeri I Ketintang Surabaya, yaitu ketuntasan individu adalah $\geq 0,68$ dan ketuntasan klasikal $\geq 0,85$ siswa yang tuntas belajarnya baik secara individual maupun secara klasikal. Untuk menentukan hasil belajar siswa berdasarkan proporsi yang diperoleh setiap siswa. Analisis data angket respon siswa tentang minat maupun motivasi akan dianalisis dengan cara mengklasifikasikan ke dalam kondisi attention (perhatian), relevance (relevansi), confidence (keyakinan), dan satis-faction (kepuasan). Total skor tiap siswa pada masing-masing kondisi dirata-rata. Jumlah total rata-rata dibagi jumlah siswa keseluruhan. Ketentuan kriteria untuk tiap kategori kondisi adalah sebagai berikut:1,00 - 1,99 = kurang baik, $2,00-2,99=$ cukup baik, 3,00 - 3,99= baik, $4,00-5,00=$ sangat baik.

\section{HASIL DAN PEMBAHASAN}

Hasil pengujian reliabilitas tiap instrument dapat dilihat pada tabel 2 dan tabel 3 .

\section{Tabel 2. Reliabilitas Instrumen Pengamatan Aktivitas Siswa dalam KBM Ujicoba II}

\begin{tabular}{lllll}
\hline \multirow{2}{*}{$\begin{array}{l}\text { Penga- } \\
\text { matan }\end{array}$} & \multicolumn{2}{l}{ Reliabilitas (\%) } & \multirow{2}{*}{ Rata-rata } \\
\cline { 2 - 4 } & RPP 01 & RPP 02 & RPP 03 & \\
\hline Siswa & 96.44 & 97.64 & 96.44 & 96.84 \\
\hline
\end{tabular}

Tabel 3. Reliabilitas Instrumen Pengamatan Aktivitas Siswa dalam KBM Ujicoba II

\begin{tabular}{lllll}
\hline \multirow{2}{*}{$\begin{array}{l}\text { Penga- } \\
\text { matan }\end{array}$} & \multicolumn{3}{l}{ Reliabilitas (\%) } & \\
\cline { 2 - 4 } & RPP 01 & RPP 02 & RPP 03 & \\
\hline Guru & 97.73 & 97.83 & 98.92 & 98.16 \\
\hline
\end{tabular}

Rata-rata reliabilitas instrumen pengamatan aktivitas siswa dalam pembelajaran dan keterlaksanaan RPP berada di atas $75 \%$. Menurut Borich (1974), instrumen pengamatan dikatakan baik apabila memiliki reliabilitas di atas $75 \%$. Dengan demikian instrumen pengamatan aktivitas siswa dalam pembelajaran yang digunakan berkategori baik. Berdasarkan hasil analisis data tes hasil belajar siswa terlihat bahwa $100 \%$ siswa tuntas hasil belajarnya. Dengan demikian secara individual maupun secara klasikal hasil belajar siswa dengan metode bermain peran tuntas.
Pengembangan perangkat pembelajaran berupa buku Ajar Siswa (BAS), isinya adalah materi bahasan peredaran darah pada manusia yang meliputi: darah dan organ peredaran darah manusia, proses peredaran darah pada manusia, gangguan organ peredaran darah manusia. Buku ajar siswa diadopsi dari buku Sains SD kelas V karangan Panut dan beberapa buku lain yang relevan dikembangkan peneliti sesuai dengan materi peredaran darah pada manusia. Berdasarkan hasil validasi tentang penilaian kelayakan BAS oleh validator 1 dan 2 diketahui skor rata-rata penilaianuntukkategori format, isi dan bahasa menunjukkan adanya peningkatan penilaian yang menunjukkan bahwa BAS sudah direvisi sesuai dengan koreksi dan saran yang diberikan oleh validator dan dinyatakan layak untuk digunakan. Berdasarkan masukkan dari validator tentang buku ajar siswa (BAS), menunjukkan bahwa BAS tersebut berbeda dari buku-buku yang telah digunakan oleh siswa selama ini. Adanya kelebihan yang ditampilkan dalam BAS yang dikembangkan oleh peneliti. Kelebihan tersebut antara lain diawal terdapat kalimat bertanya pada siswa sebelum masuk pada materi inti, tujuan adanya kalimat bertanya adalah untuk menumbuhkan rasa ingin tahu, kemampuan berpikir kritis, mendorong siswa untuk mencari informasi lebih lanjut dan BAS disusun sesuai dengan tingkat perkembangan siswa. Hal ini sesuai pendapat Arikunto (dalam Agustiningsih, 2009) yang menyebutkan bahwa BAS adalah salah satu bahan ajar yang merupakan unsur inti dalam kegiatan belajar mengajar yang harus disesuaikan dengan kebutuhan anak didik pada usia tertentu dan pada lingkungan tertentu pula. Gambar berwarna supaya BAS lebih menarik. Uraian materi dirujuk dari gambar yang sesuai pada BAS. Adanya nasehat atau pesan untuk kehidupan sehari-hari siswa serta adanya cakrawala IPA yang memberikan informasi dan pengetahuan baru pada siswa,

Lembar Kerja Siswa (LKS) yang dihasilkan ada 3 (tiga) yaitu: LKS 01 darah dan organ peredaran darah manusia, LKS 02 proses peredaran darah pada manusia, dan LKS 03 gangguan organ peredaran darah manusia. Berdasarkan hasil validasi LKS oleh validator 1 dan 2 diketahui skor ratarata penilaian untuk tiga kategori (format, isi dan bahasa) menunjukkan adanya peningkatan penilaian. Meningkatnya penilaian menunjukkan bahwa LKS sudah direvisi sesuai dengan koreksi 
dan saran validator dan dinyatakan layak untuk digunakan. Hasil validasi menunjukkan bahwa LKS yang dikembangkan berbeda dari LKS yang telah digunakan oleh siswa selama ini. Adanya kelebihan yang ditampilkan dalam LKS yang dikembangkan oleh peneliti. Dari segi isi kelebihan tersebut antara lain adanya petunjuk dan arahan mengerjakan dalam LKS lebih jelas, sehingga memudahkan siswa dalam mengerjakannya. Isi kegiatan yang ada pada LKS tidak menyimpang dari urutan materi yang diajarkan. Hal ini sesuai dengan pendapat Sudirman (dalam Agustiningsih, 2009) yang menyatakan LKS merupakan salah satu bahan ajar sebagai sumber belajar yang membawa pesan untuk tujuan pengajaran dan lembar kegiatan yang diupayakan untuk dikuasai oleh siswa. Gambar yang ditampilkan dalam LKS berwarna dan disesuaikan dengan kegiatan yang diberikan. Bahasa yang digunakan dalam LKS lebih komunikatif, struktur bahasa sederhana disesuaikan dengan taraf perkembangan anak, kalimat tidak mengandung arti ganda sehingga mendorong anak untuk mengerjakan LKS. Lembar kegiatan siswa yang dikembangkan sesuai dengan standar validitas yang ditentukan oleh Badan Standar Nasional Pendidikan (BSNP).

Rencana Pelaksanaan Pembelajaran(RPP) yang dihasilkan menunjukkan bahwa komponen RPP yang dikembangkan sudah terpenuhi, yaitu identitas sekolah, identitas kelas, nama guru, nama mata pelajaran, standar kompetensi (SK), kompetensi dasar (KD), indikator, tujuan pembelajaran, garis besar materi pelajaran, kegiatan belajar mengajar, alat dan bahan, serta penilaian. memiliki kualitas yang baik dan sudah layak digunakan sebagai perangkat. Sesuai dengan yang tercantum dalam PP nomor 19 tahun 2005 Bab IV tentang standar proses, pada pasal 20 yang menyebutkan bahwa perencanaan proses pembelajaran meliputi silabus dan rencana pelaksanaan pembelajaran yang memuat sekurangkurangnya tujuan pembelajaran, materi ajar, metode pengajaran, sumber belajar, dan penilaian hasil belajar. Berdasarkan hasil penilaian kelayakan RPP oleh validator 1 dan 2 pada BAB III, diketahui skor rata-rata penilaian untuk kategori format, isi dan bahasa menunjukkan adanya peningkatan penilaian. Meningkatnya penilaian menunjukkan bahwa RPP sudah direvisi sesuai dengan koreksi dan saran yang diberikan oleh validator.

Tes Hasil Belajar yang dikembangkan terdiri dari 25 butir soal pilihan ganda dengan 4 pilihan jawaban dan 3 butir soal uraian. THB merupakan butir-butir tes yang dikembangkan dengan tujuan untuk mengevaluasi hasil belajar siswa berdasarkan tujuan pembelajaran yang ingin dicapai. THB mencakup kisi-kisi tes hasil belajar dan butir soal dengan mengukur tingkatan ranah kognitif dari $\mathrm{C} 1$ sampai C6. Berdasarkan hasil penilaian kelayakan THB oleh validator 1 dan 2 diketahui skor ratarata penilaian untuk tiga komponen validitas isi, komponen bahasa dan penulisan soal menunjukkan adanya peningkatan penilaian. Meningkatnya penilaian menunjukkan bahwa THB sudah direvisi sesuai dengan koreksi dan saran yang diberikan oleh validator serta komponen-komponen penulisan THB telah terpenuhi dengan benar. Berdasarkan hasil validasi THB pada BAB III, menunjukkan bahwa THB yang dikembangkan sudah dapat digunakan untuk mengukur hasil belajar siswa. Hal ini dapat diketahui dari komponen penilaian THB yang sudah terpenuhi dengan baik meliputi fungsinya kalimat dalam soal tidak mengandung arti ganda, rumusan kalimat soal komunikatif, menggunakan bahasa yang sederhana bagi siswa, mudah dipahami, dan menggunakan bahasa yang dikenal siswa. Kejelasan perumusan petunjuk pengerjaan soal. Soal disesuaikan dengan materi yang telah diberikan dan tujuan soal jelas.

Implementasi Perangkat Pembelajaran, menunjukkan aktivitas siswa yang dominan selama pelaksanaan tiga RPP diketahui bahwa aktivitas siswa selama kegiatan belajar mengajar secara umum telah melakukan belajar aktif dan pembelajaran berpusat pada siswa (Student-Centered Learning) dan instrumen pengamatan aktivitas siswa selama pelaksanaan tiga RPP dengan menggunakan metode bermain peran juga reliabel.

Keterlaksanaan pembelajaran ditinjau dari 4 kategori yaitu pendahuluan, kegiatan inti, kegiatan penutup, dan suasana kelas penerapan RPP terlaksana dengan baik pada ujicoba serta reliabilitas instrumen pengamatan keterlaksanaan RRP juga reliabel.

Tes Hasil Belajar Siswa berdasarkan pembahasan hasil belajar siswa menunjukkan bahwa kegiatan pembelajaran aktif dengan menggunakan metode bermain peran pada pokok bahasan peredaran darah manusia dapat membantu siswa untuk mencapai hasil belajar yang maksimal. Ini sesuai dengan pendapat Zaini (2007) bahwa dengan belajar aktif peserta didik diajak turut serta dalam semua proses pembelajaran, tidak hanya mental 
akan tetapi juga fisik, sehinngga peserta didik akan merasakan suasana lebih menyenangkan dan hasil belajar dapat dimaksimalkan. Hal ini juga didukung teori Piaget (Trianto,2007) yang menyatakan bahwa perkembangan kognitif anak sebagian besar ditentukan oleh manipulasi dan interaksi aktif siswa dengan lingkungan belajarnya.

Berkaitan dengan keterlaksanaan pembelajaran juga dikuatkan dari hasil penelitian yang dilakukan (Mataheru.2014:169) diantaranya disimpulkan bahwa: (1) keefektifan pembelajaran berdasarkan aktivitas guru pada pertemuan pertama 92,3\%, pertemuan kedua $76,9 \%$, dan pertemuan ketiga $84,6 \%$, (2) keefektifan pembelajaran berdasarkan aktivitas siswa pada pertemuan pertama $89,8 \%$, pertemuan kedua $76,8 \%$, dan pertemuan ketiga $82,8 \%$; (3) respons positif guru yang terdiri dari sangat setuju dan setuju mencapai $93,1 \%$, (4) respons positif siswa yang terdiri dari sangat setuju dan setuju mencapai 92,5\%, dan (5) dari 21 orang siswa yang mengikuti tes hasil belajar ternyata 19 siswa $(90,5 \%)$ mencapai KKM. Demikian juga menurut De Poster \& Hernaeki (dalam Astaman, 2014:171) mengungkapkan bahwa gaya belajar yang sering dikenal dengan modalitas adalah kunci untuk mengembangkan kinerja dalam pekerjaan di sekolah dan dalam situasi antar pribadi.

Respon siswa yang positif terhadap pembelajaran dapat dilihat dari ketuntasan belajar siswa pada ujicoba sudah mencapai ketuntasan individual maupun klasikal, dan ketuntasan belajar siswa pada ujicoba sudah mencapai ketuntasan individual maupun klasikal sebesar 100\%. Respons siswa yang positif terhadap pembelajaran juga ditunjukkan dengan aktivitas siswa yang aktif selama kegiatan belajar mengajar. Respons siswa secara umum menunjukkan bahwa minat dan motivasi siswa terhadap pembelajaran aktif dengan menggunakan metode bermain peran adalah baik dan positif. Dengan demikian pengembangan perangkat pembelajaran aktif dengan menggunakan metode bermain peran baik dan layak untuk digunakan karena dapat membuat siswa aktif dalam pembelajaran, dan dapat menuntaskan hasil belajar siswa pada pokok bahasan peredaran darah manusia.

Berdasarkan fakta dapat dinyatakan bahwa temuan penelitian ini sebagai berikut. Pertama, perangkat pembelajaran yang dikembangkan adalah perangkat pembelajaran IPA dengan menggunakan metode bermain peran yang meliputi: rencana pelaksanaan pembelajaran, lembar kerja siswa (LKS), bahan ajar siswa dan tes hasil belajar siswa (THB). Kualitas perangkat pembelajaran yang sudah divalidasi dan dinilai menunjukkan sudah baik dan layak untuk digunakan. Kelayakan perangkat pembelajaran juga dilihat dari keaktivan siswa selama pembelajaran aktif, keterlaksanaan RPP berkategoribaik, hasil belajar siswa sudah mencapai ketuntasan, respon siswa terhadap pembelajaran positif, sensitivitas butir soal bernilai positif dan rata-rata reliabilitas instrumen di atas $75 \%$. Kedua, aktivitas belajar siswa yang dominan adalah mensimulasikan kegiatan bermain peran, mengamati dan memperhatikan kegiatan bermain peran dan membahas LKS. Ketiga, aktivitas belajar siswa yang dominan menunjukkan bahwa pembelajaran terpusat pada siswa dan siswa aktif dalam pembelajaran dengan menggunakan metode bermain peran. Keempat, keterlaksanaan rencana pembelajaran menggunakan metode bermain peran adalah baik, yaitu bahwa guru sudah mampu mengelola pembelajaran sesuai sintaks pada pembelajaran aktif dengan menggunakan metode bermain peran yang meliputi: menjelaskan metode bermain peran, membagi peran, mengarahkan siswa mengenai langkah-langkah yang akan disimulasikan, mengatur dan mengamati jalannya simulasi dan mengadakan refleksi atau evaluasi kegiatan simulasi dengan menggunakan metode bermain peran. Kelima, hasil belajar siswa setelah mengikuti pembelajaran aktif dengan metode bermain peran mencapai ketuntasan individual ujicoba I sebesar $80 \%$ dan ketuntasan individual ujicoba II sebesar $83 \%$. Ketuntasan tujuan pembelajaran sebesar $92 \%$ pada Ujicoba I dan $100 \%$ pada Ujicoba II.

Berdasarkan hasil penelitian (Patty, 2015), terbukti bahwa; perangkat pembelajar dapat PWIM untuk pembelajaran menulis kosakata pada siswa kelas II SD Inpres 26 Batumerah, setelah divalidasi, dilakukan uji keterbacaan, dan diujicobakan telah menghasilkan perangkat pembelajaran yang memenuhi kriteriabaik (valid). Hal ini ditunjukkan oleh: (1) ke-5 validator memberikan rata-rata penilaian 3,5 terhadap RPP, BS, dan LKS; (2) keefektifan pembelajaran berdasarkan aktivitas guru pada pertemuan pertama $80 \%$, pertemuan kedua 90\%; (3) keefektifan pembelajaran berdasarkan aktivitas siswa pada pertemuan pertama $80,8 \%$, pertemuan kedua 95,8. Kelima, respon siswa terhadap pembelajaran yang meliputi minat dan 
motivasi siswa selama mengikuti pembelajaran dengan menggunakan metode bermain peran adalah positif. Pembelajaran dengan menggunakan metode bermain peran dapat membangkitkan minat dan motivasi siswa pada materi pelajaran, dapat mengkaitkan pengetahuan siswa, tumbuhnya rasa percaya diri pada siswa, dan kepuasan pada diri siswa terhadap pembelajaran dengan mengunakan metode bermain peran.

\section{SIMPULAN DAN SARAN}

\section{Simpulan}

Hasil validasi perangkat pembelajaran berupa, buku ajar siswa, LKS, RPP dan THB menunjukkan bahwa kualitas perangkat pembelajaran yang dikembangkan sudah baik dan layak untuk digunakan. Hasil penelitian ini juga menunjukkan bahwa: (1) aktivitas belajar siswa yang dominan selama pembelajaran adalah mensimulasikan kegiatan bermain peran sebesar $15.6 \%$, (2) keterlaksanaan pembelajaran berkategori baik, (3) ketuntasan hasil belajar siswa secara klasikal 100\%, dan (4) respon siswa yang meliputi minat dan motivasi siswa terhadap pembelajaran aktif dengan menggunakan metode bermain peran berkategori baik. Respon siswa menunjukkan minat dan motivasi positif, sensivitas butir soal bernilai positif dan rata-rata reliabilitas instrumen pengamatan di atas $75 \%$. Dengan demikian pengembangan perangkat pembelajaran aktif dengan menggunakan metode bermain peran baik dan layak untuk digunakan karena dapat membuat siswa aktif dalam pembelajaran, dan dapat menuntaskan hasil belajar siswa pada pokok bahasan peredaran darah manusia.

\section{Saran}

Dari hasil penelitian dan fakta di lapangan ditemukan kenyataan bahwa dari sisi pengetahuan dan kebutuhan bahan pembelajaran untuk mengembangkan lebih lanjut hasil atau produk penelitian berupa buku ajar siswa, LKS, RPP, dan THB dengan melakukan revisi, validasi, dan uji lapangan sekala luas.

\section{DAFTAR RUJUKAN}

Agustiningsih. 2006.Penerapan Pembelajaran Aktif (Active Learning) dengan Strategi Acting Out pada Materi Sistem Respirasi di SMA Negeri I Menganti Gersik. Tidak dipublikasi Surabaya: UNESA.
Agustiningsih. 2009. Pengembangan Perangkat Pembelajaran IPA SD Berorientasi Pembelajaran Multimetode Pada Pokok Bahasan Sistem Pernapasan Manusia Di Kelas V SD. Tesis tidak dipublikasi Surabaya;Unesa.

Astaman, I. G. \& Dewa N. S. 2014. Penerapan Model Pembelajaran Savi Bermuatan Peta Pikiran untuk Meningkatkan Motivasi dan Hasil Belajar IPA Siswa Kelas V SD. Jurnal Sekolah Dasar, 23(2):43-56.

Dwiningsih, K. 2005. Pembelajaran Kimia melalui Permainan Card Sorting Materi Sistem Periodik Unsur-unsur di SMA.Tesis. Tidak dipublikasikan. Surabaya: UNESA.

Gina, L. 2008. Acitive Learning, Increasing Flow In The Classroom. Pat Hollingsworth: Norwalk.

Haak, D. C., HilleRisLambers, J., Pitre, E., \& Freeman, S. (2011). Increased structure and active learning reduce the achievement gap in introductory biology. Science, 332(6034), 1213-1216.

Ibrahim, M. 2006. Asesmen Berkelanjutan, Seri Pembelajaran Inovatif. Surabaya: Unesa University Press.

Lewis, C. 2002. Lesson Study: A Handbook Of Teacher-Led Instructional Change. Philadelphia: Research for Better Schools.

Mataheru, W. 2014. Pengembangan Model Team Assisted Individualization Pada Materi Operasi Hitung Bilangan Bulat Di Kelas V SD. Jurnal Sekolah Dasar. 23(2):74-85.

Mintohari. 2005. Konsep Dasar IPA Biologi Pendidikan Guru Sekolah Dasar. Surabaya: UNESA .

Mulyasa, E. 2006. Kurikulum Tingkat Satuan Pendidikan. Bandung: Rosdakarya.

Muslimin, I. 2006. Pembelajaran Kooperatif. Surabaya: UNESA University Press.

Nur, M. 2002. Psikologi Pendidikan Fondasi untuk Pengajaran. Surabaya: UNESA.

Patty, R. 2015. Pengembangan Model Induktif Kata Bergambar pada Pembelajaran Menulis Permulaan di Kelas II SD. Jurnal Sekolah Dasar. 24(2):37-48.

Pettenger,M.,West,D.,\&Young,N.(2014).Assessing the impact of role play simulations on learning in Canadian and US classrooms. International Studies Perspectives, 15(4), 491-508.

Pusat Kurikulum, 2006. Kurikulum Tingkat Satuan Pendidikan Mata Pelajaran IPA SD.Jakarta: Depdiknas. 
Russell, C., \& Shepherd, J. (2010). Online role-play environments for higher education. British Journal of Educational Technology, 41(6), 992-1002.

Settles, B. (2010). Active learning literature survey. University of Wisconsin, Madison, 52 (55-66), 11:68-79.

Sukandi,U.2003.Belajar Aktif dan Terpadu.Jakarta: Duta Graha Pustaka.

Thiagarajan, Semmel, D.S \& Semme, M.I. 1974. Instructional Development for Training Teachers Of Exceptional Children A Sourcebook. Blomington: Center for Inovation on Teaching The Handicaped.
Trianto. 2007. Model-Model pembelajaran Inovatif Berorientasi Konstruktivistik. Jakarta: Prestasi Pustaka Publisher.

Uno, H.B. 2006. Teori Motivasi dan Pengukurannya. Jakarta: Bumi Aksara.

Yulianto, B. 2008. Model-Model Pembelajaran Inovatif. Surabaya: Unesa University Press.

Zaini, H. 2007. Strategi Pembelajaran Aktif Enhancing Teaching and Learning. Yogyakarta: CTSD. 